\title{
The epidemiology of mesothelioma in historical context
}

\author{
J.C. McDonald, A.D. McDonald
}

The epidemiology of mesothelioma in historical context. J.C. McDonald, A.D. McDonald. (C)ERS Journals Ltd 1996.

ABSTRACT: Primary malignant mesothelial tumours were recognized by pathologists before asbestiform minerals (chrysotile, crocidolite and amosite) were mined commercially. The discovery, 40 yrs ago, of a causal link with crocidolite and the wide-ranging epidemiological studies which followed are the subject of this review.

Early case-control and descriptive surveys, supplemented by cohort studies in insulation workers and chrysotile miners, quickly demonstrated major occupational and geographical differences, with high risk in naval dockyard areas and in the heating trades. In the 1980s, reliable cohort surveys showed that in mining and in the manufacture of asbestos products the mesothelioma risk was much higher when exposure included crocidolite or amosite than chrysotile alone. However, qualitative and quantitative information on exposure was too often inadequate for this evidence to be conclusive. Well-controlled lung fibre analyses have reduced these deficiencies and demonstrated the probable implications of the greater biopersistence of amphibole fibres. Chrysotile for industrial use often contains low concentrations of fibrous tremolite, which may well explain the few cases of mesothelioma associated with this type of asbestos.

Progress in this field has been much retarded by controversy, for which the 20 year gap between the availability of reliable estimates of risk for the mining of chrysotile and that for crocidolite or amosite may have been largely responsible. Eur Respir J., 1996, 9, 1932-1942.
Dept of Occupational and Environmental Medicine, National Heart \& Lung Institute, Imperial College, London, UK.

Correspondence: J.C. McDonald Dept of Occupational and Environmental Medicine

National Heart \& Lung Institute Imperial College

London UK

Keywords: Amphiboles biopersistence chrysotile lung analyses mesothelioma tremolite

Received: March 191995 Accepted after revision May 31996

\section{A new industry, a new disease}

Asbestos, the "magic mineral", was known to the ancient Egyptians and mentioned by Pliny, but only mined and manufactured in any quantity since about the 1890s. At that time, exploitation of large deposits of white asbestos (chrysotile) in Canada and Russia and blue asbestos (crocidolite) in South Africa began to develop rapidly. Early in this century, a brown asbestos, named amosite after the village of Amosa and the company which discovered it, together with deposits of chrysotile were also mined in South Africa. Crocidolite was later found and mined in Western Australia after the second world war and in lesser amounts elsewhere.

Primary malignant pleural tumours have been recognized at least since 1870, when WAGNER [1] published a report on a case of "tubercle-like" lymphadenoma of the pleura. In 1943, SACCONE and CoBlenz [2], in a review of cases published before 1940, referred to the tumour as an "endothelioma", and mentioned a report by Lieutaud in 1767 of two such tumours in a series of 3,000 autopsies. They went on to say that, as knowledge of the tumour's existence spread, reports appeared with increasing frequency. These authors identified 41 cases in seven series published between 1910 and 1938 in a total of some 46,000 autopsies $(0.9 \%)$, and added two cases of their own among 1,000 autopsies. The male to female ratio overall was 1.8 , with $50 \%$ of subjects aged $40 \mathrm{yrs}$ or more.

SAcCone and Coblenz [2] discussed the confusion which existed over pathology due, in their opinion, to the tumour's rarity and lack of characteristic histology. From descriptions and photomicrographs of the 41 cases mentioned, they concluded that some at least were of other diseases, such as bronchogenic carcinoma. In view of diverging opinions at that time on the origin of cells lining serous cavities from which the tumour originated, they suggested that the name "pleuroma" be used. Later, however, the term "mesothelioma" became more generally accepted.

\section{The link with asbestos}

The suggestion that mesothelioma resulted from occupational exposure to asbestos was first made by GLOYNE [3], in Britain in 1935. In Germany, WeDLER [4] described two cases in men with asbestosis and WeIss [5] one case in a naval dockyard worker. LEICHER [6] was the first to report a case of peritoneal mesothelioma, in a textile spinner. At a scientific meeting in 1952, CARTIER [7], then in charge of the industrial medical clinic at Thetford Mines, Quebec, Canada, reported eight cases of respiratory cancer, two of which he described as pleural tumours. In his opinion, two such rare cancers in a small series of only eight cases suggested an occupational origin. A report in 1960 by WAGNER et al. [8] of 33 cases of mesothelioma mainly from the crocidolite-mining area in the north west Cape Province of South Africa put the association beyond reasonable doubt. Of the 33 cases, 28 were in persons who had worked in the mines or lived close to them. The pathological material available was limited to thoracic contents, and peritoneal tumours were not seen. 
Table 1. - Early case-control studies of mesothelioma giving definite or probable occupational exposure to asbestos

\begin{tabular}{|c|c|c|c|c|c|c|c|c|}
\hline $\begin{array}{l}\text { First } \\
\text { author }\end{array}$ & Year & [Ref.] & Place & $\begin{array}{c}\text { Years } \\
\text { diagnosed }\end{array}$ & $\begin{array}{l}\text { Cases/ } \\
\text { controls }\end{array}$ & $\underset{\%}{\text { Male }}$ & $\begin{array}{l}\text { Occupationally } \\
\text { exposed } \%\end{array}$ & RR \\
\hline Elmes & 1965 & [10] & Belfast, UK & 1950-1964 & $42 / 42$ & 95 & 76 & 3.6 \\
\hline Newhouse & 1965 & [11] & London, UK & 1917-1964 & $76 / 76$ & 49 & 41 & 3.9 \\
\hline McEwEN & 1970 & [12] & Scotland, UK & 1950-1967 & $80 / 80$ & 91 & 58 & 4.2 \\
\hline McDonald & 1970 & [13] & Canada & 1960-1968 & $165 / 165$ & 65 & 21 & 7.0 \\
\hline RUBINO & 1972 & [14] & Piedmont, Italy & 1960-1970 & $50 / 50$ & 64 & 12 & 6.0 \\
\hline ASHCROFT & 1973 & [15] & Tyneside, UK & 1948-1967 & $27 / 56$ & 88 & 93 & 2.3 \\
\hline HAIN & 1974 & [16] & Hamburg, Germany & 1958-1968 & $150 / 150$ & 71 & 58 & 6.3 \\
\hline ZIELHUIS & 1975 & [17] & The Netherlands & 1969-1971 & $67 / 67$ & 94 & 72 & 4.0 \\
\hline
\end{tabular}

RR: relative risk; [Ref.]: reference number.

\section{The 1964 New York Conference}

At a conference on the "Biological Effects of Asbestos", a study by the Selikoff group of New York and New Jersey members of the International Association of Insulators and Asbestos Workers was a key event [9]. Of 632 males at work in 1942, 255 had died by 1962, three from pleural mesothelioma, and by 1964, 10 of 307 deaths were from mesothelioma - four pleural and six peritoneal. Two important case-control studies were also presented at this conference and later published (table 1). In the first of these, ELMES et al. [10] studied 42 cases of mesothelioma and 42 controls in Belfast, UK, matched for date, sex and age. Occupational histories were obtained from the living and from relatives of those who had died. Thirty six cases had a history of occupational exposure to asbestos, mainly in shipyards, compared with nine controls. The second study was by NewHOUSE and THOMPSON [11] of 83 patients with mesothelioma diagnosed at a hospital close to the large Cape Asbestos factory in the east end of London, UK, which had opened in 1913. The control series comprised patients admitted later with other diseases, matched for sex and age. The authors acknowledged that neither these nor the interview methods were ideal but concluded that the case-control comparisons of occupational and residential histories were probably valid. Of 76 pairs, 18 cases $(24 \%)$ had been employed at the asbestos factory and eight $(11 \%)$ as insulators or laggers, compared with one $(1 \%)$ and four $(5 \%)$ controls, respectively. A further nine cases $(12 \%)$ were in persons who had lived in the same house as an asbestos worker and were indirectly exposed, compared with one control (1\%). Only crocidolite was used in the factory until 1926, when small quantities of chrysotile and amosite were introduced.

At the end of the 1964 conference, a Working Group under the auspices of the International Union against Cancer (UICC) reviewed the papers which had been presented and made a series of recommendations, with considerable emphasis on the need for more extensive epidemiological studies of mesothelioma and on the importance of asbestos fibre type [18]. As fibre of more than one type of asbestos was almost always used in manufacture it was suggested that research should concentrate on countries where it was mined or milled as the problem might then be less serious. Initially, this approach was taken only in the extensive chrysotile mines and mills of Quebec, Canada, and in the smaller chrysotile industry of northern Italy. Starting in 1966, all 30,000 current and previous employees of the Quebec industry who had worked for at least one calendar month were listed. In addition to comprehensive studies of respiratory morbidity [19], mortality was investigated in a cohort of some 12,000 workers, born 1891-1920. Among 2,413 male deaths in the cohort to the end of 1966, there was a modest, exposure-related excess of lung cancer but only three deaths were from mesothelioma [20]. This prompted the need for studies of mesothelioma on a wider geographical scale. Almost 20 years passed before comparable studies were made in the production of crocidolite or amosite in South Africa and Australia, with a resulting controversy, which will be discussed at the end of this review.

\section{Widening the epidemiological net}

\section{Case-control studies}

From the end of 1967, all pathologists in Canada (over 400) were approached periodically concerning any fatal case of primary malignant mesothelial tumour diagnosed at autopsy or biopsy and, in 1972, the survey was extended to all pathologists (almost 7,000) throughout the USA. On each occasion, a response was obtained from nearly all of them [21]. The pathologists were then visited to discuss the diagnoses and to collect reports and material for panel review. A control with metastatic lung disease from a primary tumour outside the chest, matched for date, sex and age was selected from the same pathology file as the case. Relatives were interviewed, generally by a public health nurse ignorant of the case/control status, and detailed residential and occupational histories recorded. Jobs were coded blind, using a list classified by four different expert groups according to the probability of asbestos exposure.

Of 344 male cases of mesothelioma, 188 (55\%) compared with $78(23 \%)$ controls fell into one of the five defined exposure groups, presented in table 2. Insulation work - an infrequent occupation in controls - showed the highest relative risk (46.1). Asbestos production and manufacture was next in relative risk (6.1), almost wholly due to factory work. Employment in heating trades, shipyards and construction, after excluding insulation work, gave a lower combined risk (3.4). Occupational exposure to asbestos was recorded in only two of 162 female cases and no control. In three female cases and one control, exposure had been in the home to the clothing of a chrysotile production worker and in five cases and one 
Table 2. - Case-control study of 344 male primary malignant mesothelial tumours of pleura and peritoneum, Canada 1960-1972, and USA 1972 [21]

\begin{tabular}{lccr}
\hline $\begin{array}{l}\text { Occupational group with definite } \\
\text { or probable asbestos exposure }\end{array}$ & $\begin{array}{c}\text { Cases } \\
(\mathrm{n}=344)\end{array}$ & $\begin{array}{c}\text { Controls } \\
(\mathrm{n}=344)\end{array}$ & $\mathrm{RR}$ \\
\hline A Insulation & 27 & 1 & 46.1 \\
B Asbestos production & 25 & 7 & 6.1 \\
$\quad$ \& manufacture (excl. A) & 4 & 2 & \\
$\quad$ Mining and milling & 21 & 5 & \\
$\quad$ Manufacture & 70 & 27 & 4.4 \\
C Heating trades (excl. A, B) & 21 & 13 & 2.8 \\
D Shipyards (excl. A, B, C) & 45 & 30 & 2.6 \\
E Construction (excl. A, B, C, D) & 55 & 90 & 1.0 \\
F Other (excl. A, B, C, D, E) & 101 & 176 & 1.0 \\
G None & & & \\
\hline
\end{tabular}

RR: relative risk; excl.: excluding

control to that of an employee engaged in insulation or manufacture. Neighbourhood exposure was investigated by comparing the number of cases and controls who had lived within 20 miles of a chrysotile mine, excluding those occupationally or domestically exposed. No case with meso-thelioma but two controls had lived within 20 miles of a chrysotile mine in Quebec, Canada, and one case and two controls within 20 miles of a mine in California, USA.

Further evidence of an increased risk in shipyard areas was afforded by four of five other case-control studies published in the 1970s (table 1). Except for the report from northern Italy, where most of the occupational exposures were in or near Turin, shipyard exposures were mainly to blame.

\section{Analyses of incidence and mortality}

In the Canadian surveys described above, the annual incidence for 1960-1966 was one case per million persons - about 1.5 in males and 0.8 in females; however, there was probably under-reporting during these early years. In 1966-1972, the incidence in Canada was 2.9 per million males and 1.4 per million females; and in the USA in 1972, the corresponding rates were 2.7 and 0.8 per million. Cases in which a biopsy or autopsy specimen could be obtained were later reviewed by the Canadian and American mesothelioma panels of pathologists on a probability scale, first on histology, and then with clinical but not occupational information. In Canada, the incidence in Quebec was higher than that in Ontario, but fewer Quebec cases were accepted by the panel than for Ontario, and the corrected incidence in the two provinces was similar. These estimates were used in 1975 in a geographical analysis of all known cases of mesothelioma worldwide in areas where reported cases could be linked to population estimates. By applying age- and sexspecific rates found in Canada, the number of mesotheliomas expected on this basis was compared with the number observed. High ratios were found in many European shipyard cities, notably Walcheren, The Netherlands (23.3), Wilhelmshaven, Germany (21.5) and Plymouth, UK (14.3). In two locations with large asbestos manufacturing industries, there were also high ratios: Dresden, Germany (16.8) and the Manville-Somerville area of New Jersey, USA (26.5) [22].
It was evident that, even in the early 1970s, mesothelioma mortality in North America was already two or three times higher in males than females. This pattern became apparent in most industrialized countries and was followed by a steady upward trend in male mortality, which still continues. The implications of the much lower annual increase in females will be mentioned in a later section as evidence on the question of nonoccupational asbestos exposure. The steep rise in males, which probably began in the 1940s, is well explained as reflecting a parallel increase in the industrial use of asbestos, from about 1910, having taken account of a 30-40 year latency [23]. As a result of this increase, mesothelioma is currently responsible for some 20 deaths per million male population in Western Europe and North America compared with an estimated 1 to 2, 30-40 yrs ago. In early studies, only a minority of male cases were attributable to occupational exposure to asbestos, whereas, depending on location, up to $90 \%$ now are.

As the epidemic has evolved in the UK, the overall distribution of occupations which have been responsible has remained much the same but there is evidence that the contribution of work in shipyards has fallen but has increased in construction [24]. How long the mesothelioma epidemic can be expected to last is an important but difficult question. Estimated crudely from the industrial use of asbestos, it seemed possible that the peak might be reached in about year 2000; falling thereafter over a period of about 40 yrs [23]. Results of a recent and more sophisticated analysis of UK data are less optimistic and suggest that the peak may not be reached until 2010-2020 [25]. If true, this would point to the greatly increased importation of amosite for construction use in the UK during the 1960s and 1970s. However, these projections are highly dependent on the extent to which mesothelioma is better diagnosed and ascertained now than it used to be.

\section{Other causal agents}

Some 20 yrs after the pioneering work of WAGNER et al. [8] in South Africa, a discovery in some ways more dramatic was made by BARIS et al. [26] in Turkey. In some small villages in a circumscribed volcanic area of central Cappadocia, an extraordinarily high mortality from mesothelioma was observed in the local population. In Karäin, a village of 575 inhabitants, in a 5 year period, 1970-1974, 24 from a total of 55 deaths were attributed to pleural mesothelioma. In Tuskoy, a larger village, both pleural and peritoneal tumours were in considerable excess. The rocks and soil of the affected area are rich in zeolite minerals, a common constituent of volcanic tuff. Erionite, a specific zeolite, was found in fibrous form in soil and rock samples and in respirable concentrations in both villages. Experimentally, these fibres are highly carcinogenic and readily produce mesothelial tumours in rats and mice [27]. The epidemiological investigations, although mainly descriptive rather than analytical, leave little doubt that these fibres are the cause of this unparalleled incidence of tumours in man [27]. Deposits of fibrous erionite are common in many areas of the world but to date there is no certain evidence, other than in Turkey, of an association with mesothelioma. 
In a report from India, five cases of malignant mesothelioma were reported in sugar cane workers, with the suggestion that organic fibres might have been the cause [28]. Some support was obtained from Louisiana, USA, where two cases of mesothelioma were observed in similar circumstances [29]. In an electron microscopic study of ashed sugar cane leaf, silicon was found deposited along the hypoderm resulting in fibres $0.85 \mu \mathrm{m}$ in diameter and 10-100 $\mu \mathrm{m}$ in length. The possibility that such "biogenic silica" fibres might be causally related to the tumour awaits further epidemiological study.

That mesothelioma might occur in workers exposed to man-made mineral fibres (MMMFs) was investigated in three large cohorts totalling some 41,185 workers employed in their manufacture in Europe and North America. Only four deaths were ascribed to the disease in a total of 7,862 deaths from all causes, one in a man also exposed to amosite [30]. Exposure levels in MMMF manufacture are extremely low, however.

\section{Systematic cohort mortality studies}

The 1980s saw the publication of results from a considerable number of cohort studies in specific occupational groups, which differed in industrial process and in type of asbestos fibre to which the workers were exposed. The main and most recent findings from the more important of these investigations, classified by predominant industry, are summarized in three tables: mining and milling in table 3; manufacture of asbestos/cement products, asbestos textiles and asbestos friction products in table 4; and miscellaneous industrial groups in table 5. In a few of these studies, attempts were made to estimate exposure in terms of intensity and duration but in none could the level of exposure to individual fibre types be reliably assessed.

\section{Mining and milling}

The large cohort of chrysotile miners and millers in Quebec, Canada, first reported in 1971 has been followed ever since with updated results published periodically, the most recent in 1993 [31]. By this time, almost 80\% of the cohort had died and the youngest survivors were in their mid 70s. From a total of over 8,000 deaths, 38 were probably due to mesothelioma - all pleural with one possible exception - a proportional mortality of just under $0.5 \%$. A cohort of approximately one tenth the size from Balangero in northern Italy gave similar results. No comparable data on amphibole miners were available

Table 3. - Cohort mortality studies of male asbestos miners and millers ${ }^{\star}$

\begin{tabular}{|c|c|c|c|c|c|c|c|c|c|c|c|}
\hline \multirow{3}{*}{$\begin{array}{l}\text { First } \\
\text { author }\end{array}$} & \multirow[t]{3}{*}{ Year } & \multirow[t]{3}{*}{ [Ref.] } & \multirow[t]{3}{*}{ Country } & \multirow{3}{*}{$\begin{array}{c}\text { Subjects } \\
n\end{array}$} & \multicolumn{6}{|c|}{ Deaths } & \multirow{3}{*}{$\begin{array}{l}\text { Predominant } \\
\text { fibre }\end{array}$} \\
\hline & & & & & \multicolumn{2}{|c|}{ All causes } & \multicolumn{2}{|c|}{ Lung cancer } & \multicolumn{2}{|c|}{ Mesothelioma } & \\
\hline & & & & & $\mathrm{n}$ & $\%$ & $\mathrm{n}$ & SMR & $\mathrm{n}$ & PMR/1000 & \\
\hline MCDONALD & 1993 & [31] & Canada & 10918 & 7312 & 67 & 545 & 1.33 & 33 & 4.5 & Chrysotile \\
\hline Piolatto & 1990 & [32] & Italy & 952 & 427 & 45 & 22 & 1.11 & 2 & 4.7 & Chrysotile \\
\hline \multirow[t]{2}{*}{ Sluis-CREMER } & 1992 & [33] & RSA (1) & 3212 & 648 & 20 & 26 & 1.38 & 4 & 6.2 & Amosite \\
\hline & & & (2) & 3430 & 423 & 12 & 27 & 2.03 & 20 & 47.3 & Crocidolite \\
\hline ARMSTRONG & 1988 & [34] & Australia & 6505 & 820 & 13 & 91 & 2.64 & 32 & 39.0 & Crocidolite \\
\hline MCDONALD & 1986 & [35] & USA & 406 & 165 & 41 & 21 & 2.45 & 4 & 24.2 & Tremolite \\
\hline
\end{tabular}

*: including vermiculite miners exposed to fibrous tremolite. [Ref.]: reference number; SMR: standardized mortality rate; PMR: proportional mortality rate.

Table 4. - Cohort mortality studies of male workers in asbestos manufacturing industries

\begin{tabular}{|c|c|c|c|c|c|c|c|c|c|c|c|}
\hline \multirow{3}{*}{$\begin{array}{l}\text { First } \\
\text { author }\end{array}$} & \multirow[t]{3}{*}{ Year } & \multirow[t]{3}{*}{ [Ref.] } & \multirow[t]{3}{*}{ Country } & \multirow{3}{*}{$\begin{array}{c}\text { Subjects } \\
\mathrm{n}\end{array}$} & \multicolumn{6}{|c|}{ Deaths } & \multirow{3}{*}{$\begin{array}{c}\text { Amphibole } \\
\text { content }\end{array}$} \\
\hline & & & & & \multicolumn{2}{|c|}{ All causes } & \multicolumn{2}{|c|}{ Lung cancer } & \multicolumn{2}{|c|}{ Mesothelioma } & \\
\hline & & & & & $\mathrm{n}$ & $\%$ & $\mathrm{n}$ & SMR & $\mathrm{n}$ & PMR/1000 & \\
\hline \multicolumn{12}{|c|}{ Asbestos-cement } \\
\hline THOMAS & 1982 & [36] & UK & 1592 & 351 & 22 & 24 & 0.93 & 2 & \multirow{4}{*}{3.5} & \multirow{3}{*}{ Minimal } \\
\hline OHLSON & 1985 & [37] & Sweden & 1176 & 220 & 19 & 11 & 1.23 & 0 & & \\
\hline GARDNER & 1986 & [38] & UK & 1510 & 384 & 25 & 35 & 0.92 & 1 & & \\
\hline HugHES & 1986 & [39] & USA (plant 1) & 2565 & 477 & 19 & 48 & 1.17 & 2 & & \multirow{8}{*}{ Substantial } \\
\hline FINKELSTEIN & 1984 & {$[40]$} & Canada & 535 & 108 & 20 & 26 & 4.80 & 19 & \multirow{7}{*}{20.7} & \\
\hline Alies-Patin & 1985 & [41] & France & 1506 & 206 & 14 & 9 & 1.63 & 4 & & \\
\hline HuGHES & 1986 & [39] & USA (plant 2) & 4366 & 874 & 20 & 107 & 1.44 & 8 & & \\
\hline MAGNANI & 1987 & [42] & Italy & 2608 & 728 & 28 & 110 & 2.68 & 28 & & \\
\hline RAFFN & 1989 & [43] & Denmark & 7996 & 1305 & 16 & 162 & 1.80 & 13 & & \\
\hline AlBIN & 1990 & [44] & Sweden & 1929 & 592 & 31 & 35 & 2.50 & 13 & & \\
\hline Neuberger & 1990 & [45] & Austria & 2816 & 540 & 19 & 50 & 1.72 & 5 & & \\
\hline \multicolumn{12}{|l|}{ Textiles } \\
\hline MCDONALD & 1983 & [46] & USA & 2543 & 570 & 22 & 59 & 2.0 & 1 & \multirow{3}{*}{2.5} & \multirow{3}{*}{ Minimal } \\
\hline DEMENT & 1994 & [47] & USA & 1247 & 607 & 49 & 72 & 2.25 & 2 & & \\
\hline MCDONALD & 1983 & [48] & USA & 4137 & 895 & 22 & 53 & 1.05 & 14 & & \\
\hline \multirow{2}{*}{\multicolumn{12}{|c|}{ Friction products }} \\
\hline & & & & & & & & & & & \\
\hline McDonaLD & 1984 & {$[50]$} & USA & 3641 & 803 & 22 & 73 & 1.49 & 0 & 0 & Minimal \\
\hline Newhouse & 1989 & [51] & UK & 9104 & 2055 & 23 & 229 & 1.03 & 11 & 5.4 & Localized \\
\hline
\end{tabular}

For definitions see legend to table 3 . 
Table 5. - Cohort mortality studies of male and female asbestos-exposed workers in miscellaneous industries

\begin{tabular}{|c|c|c|c|c|c|c|c|c|c|c|c|}
\hline \multirow{3}{*}{$\begin{array}{l}\text { First } \\
\text { author }\end{array}$} & \multirow[t]{3}{*}{ Year } & \multirow[t]{3}{*}{ [Ref.] } & \multirow[t]{3}{*}{ Country } & \multirow{3}{*}{$\begin{array}{c}\text { Subjects } \\
\mathrm{n}\end{array}$} & \multicolumn{6}{|c|}{ Deaths } & \multirow{3}{*}{$\begin{array}{l}\text { Predominant } \\
\text { fibre }\end{array}$} \\
\hline & & & & & \multicolumn{2}{|c|}{ All causes } & \multicolumn{2}{|c|}{ Lung cancer } & \multicolumn{2}{|c|}{ Mesothelioma } & \\
\hline & & & & & $\mathrm{n}$ & $\%$ & $\mathrm{n}$ & SMR & $\mathrm{n}$ & $\mathrm{MR} / 1000$ & \\
\hline \multicolumn{12}{|c|}{ Insulation work } \\
\hline SELIKOFF & 1979 & {$[52]$} & $\begin{array}{l}\text { USA \& } \\
\text { Canada }\end{array}$ & 17,800 & 2271 & 13 & 397 & 4.24 & 175 & 77.1 & $\begin{array}{l}\text { Chrysotile } \\
\& \text { amosite }\end{array}$ \\
\hline \multicolumn{12}{|c|}{ Insulation products manufacture } \\
\hline SeIDMan & 1979 & [53] & USA & unclear & 528 & - & 76 & 5.78 & 14 & 26.5 & Amosite \\
\hline ACHESON & 1984 & [54] & UK & 4280 & 333 & 8 & 38 & 1.31 & 5 & 15.0 & Amosite \\
\hline \multicolumn{12}{|c|}{ Filter assembly } \\
\hline MCDONALD & 1978 & {$[55]$} & Canada & 199 & 56 & 28 & 8 & 2.0 & 0 & 160.7 & Crocidolite \\
\hline JONES & 1980 & [56] & UK & 1088 & 166 & 15 & 12 & 2.14 & 29 & 174.7 & Crocidolite \\
\hline TALCOTT & 1989 & [57] & USA & 33 & 28 & 85 & 8 & 15.71 & 5 & 178.6 & Crocidolite \\
\hline ACHESON & 1982 & [58] & UK (a) & 757 & 219 & 29 & 15 & 2.41 & 5 & 22.8 & Crocidolite \\
\hline & & & UK (b) & 570 & 177 & 31 & 7 & 1.45 & $1 *$ & 5.6 & Chrysotile \\
\hline \multicolumn{12}{|c|}{ Dockyard work } \\
\hline ROSSITER & 1980 & [59] & UK & 6292 & 1043 & 17 & 84 & 0.84 & 31 & 29.7 & Not stated* \\
\hline
\end{tabular}

*: also exposed to crocidolite. For definitions see legend to table 3.

until the late 1980s, when findings for crocidolite and amosite were published from South Africa and for crocidolite from Australia. At about the same time, two small cohorts of vermiculite miners in the USA, one of which had experienced substantial exposure to fibrous tremolite provided important evidence on its effects [35]. In interpreting the figures on proportional mortality in table 3 , it should be noted that the crocidolite and amosite rates were derived from cohorts of which only $12-21 \%$ had died. At that stage in the evolution of the chrysotile cohorts, the proportional mortality from mesothelioma was less than 2 per 1,000. Proportional mortality rates are a very crude indicator of risk, since they do not take levels of exposure or competing causes of death into account. Nevertheless, the data in table 3 leave little doubt that crocidolite carries a much higher risk than chrysotile, with amosite and tremolite probably somewhere in between.

\section{Manufacturing processes}

The 17 cohorts shown in table 4 were informative in that all were engaged in the manufacture of asbestos-containing products, predominantly from chrysotile but some with the planned inclusion of relatively small quantities of crocidolite or amosite. Interpretation of the results is facilitated by the fact that the proportions dead at time of analysis in each cohort were of the same order, all but one (49\%) ranging $14-31 \%$ (median $22 \%$ ).

With each of the three types of product, there was a fairly consistent difference in the proportional rates for mortality from mesothelioma between cohorts with and without exposure to amphiboles. In cement workers, the relevant rates per 1,000 were 20.7 and 3.5 , respectively; in textile workers 14.8 and 2.5 ; and in friction product workers 5.4 and 0 . To these admittedly crude comparisons, made without reference to intensity or duration of exposure, some limited detail can be added. For example, the only death in the cohort of GARDNER et al. [38] was in a man first employed in the factory less than 7 years earlier. In the friction products cohort of NEWHOUSE and Sullivan [51], all but one of the 11 cases observed were from a small group of employees who worked for a short time on a special crocidolite contract, and there was no case attributable only to chrysotile in the remainder of the cohort.

\section{Miscellaneous occupations}

Although all but one of the cohorts shown in table 5 were exposed wholly or largely to amosite of crocidolite, the data are of considerable interest. The very large cohort of American insulation workers investigated by SELIKOFF et al. [52] is one of the classic studies of asbestos epidemiology. At a stage when only $13 \%$ had died, almost $8 \%$ of deaths were attributed to mesothelioma, two thirds of which were peritoneal. Initially, it was thought that the exposure of these workers was mainly to chrysotile but it soon became clear that at least from 1930 onwards, amosite was the predominant type of asbestos used in American insulation materials. The suggestion was made at the Johannesburg Conference in 1977 that amosite rather than chrysotile might be responsible for the problem [60], but this has only recently been confirmed by lung burden analyses [61]. Two cohorts of workers exposed only to amosite in the manufacture of insulation materials, one in the USA [54] and the other in the UK [53], have provided further evidence of the capacity of this mineral fibre to cause mesothelioma. However, at face value, their levels of risk did not reach that of insulation workers employed in applying and removing these materials.

The highest recorded proportional mortality rates from mesothelioma were observed in two remarkable cohorts of males and females who worked for quite short periods of time during the early years of the second world war in England and in Canada on the installation of filter pads in military gas-masks. The pads were made from pure crocidolite believed to have come from the Wittenoom mine in Australia, where a cohort of miners and millers was studied some years later (table 3). An identical pattern in the incidence of cases began both in England and Canada 18 yrs after first exposure, and continued to grow for at least 10 more years; in the UK, new cases are still being seen almost 60 yrs later (J.S.P. Jones, personal communication). The nearest equivalent to these disastrous events was seen in a small group of employees in the manufacture of filters for cigarettes in the USA from, 
of all things, crocidolite [57]. Five cases of mesothelioma from a total of 33 deaths $(15 \%)$ were reported in that group.

Finally, a study by Rossiter and Coles [59] of over 6,000 males employed in the Devonport (Plymouth, UK) naval dockyard is worth noting. Asbestos exposures were not well-documented but certainly included an appreciable proportion of crocidolite. This was not sufficient to produce excess mortality from lung cancer but it resulted in a large number of cases of mesothelioma.

\section{Overview}

Few, if any, environmental hazards have been the object of so many cohort studies as asbestos, only some of which have been mentioned in this review. Although it would be difficult to conclude from these data that the capacity of amphibole fibres, especially crocidolite, to produce mesothelioma is not considerably greater than that of chrysotile, uncertainties remain. The problem lies in the evident complexity of the causal relationships and the many factors other than fibre type with which the crude information available on exposure in these cohorts has failed to deal. Whilst duration of exposure can be estimated fairly accurately, fibre concentrations by size and type cannot. This is a serious problem when exposures are known to have been to more than one type of asbestos, and of increasing importance where one type is sometimes contaminated by another as, for example, chrysotile by tremolite or amosite by crocidolite. There is also reason to suspect that the nature of the industrial process may affect the outcome, as the textile industry does for lung cancer but not apparently for mesothelioma. It is, therefore, hardly surprising that, with the exception of the studies by Hughes and WeILl [39] in the asbestos/ cement industry, there still exist virtually no reliable data on exposure-response for mesothelioma which take account of any of these variables. To avoid the problems of environmental exposure assessment, more recent epidemiological research has turned increasingly to the use of lung fibre burden measurements. This approach and important new insights into the disease potential of chrysotile are discussed in a later section.

\section{Nonoccupational mesothelioma}

It is clear enough that in most cases of mesothelioma, particularly in industrialized countries, there is a fairly definite history of direct or indirect exposure to asbestos at work. This has led many to suggest that all cases may be caused in this way. This hypothesis raises two separate questions: firstly, is there evidence of a background incidence of the disease before, and presumably also since, asbestos was first exploited for industrial use? and, secondly, are there some cases attributable to asbestos but resulting from exposure in the domestic, neighbourhood or general environment rather than at work? These two aspects will be considered in turn.

\section{The background hypothesis}

In a recent review of this question [62], five types of evidence were examined, all of which pointed to the probable occurrence of mesothelioma as a rare malignancy unrelated to asbestos exposure both before and since the industrial use of these fibrous minerals began at the end of the last century. The simplest evidence that cases are not all due to asbestos fibres is the high mortality from the disease in certain villages of central Turkey, to which reference has already been made. These cases were clearly caused by local deposits of fibrous erionite, a mineral with many physical and biological properties similar to crocidolite and tremolite. Deposits of fibrous erionite are widespread on the earth's surface and there is, indeed, some suggestion of related cases in proximity to deposits in the Rocky Mountain states of North America [63] but not elsewhere.

Other suggestive evidence, historical rather than geographic, has also been mentioned. It is fairly clear that primary malignant tumours of the pleura were recognized by pathologists at autopsy at the end of the last century, before the industrial use of asbestos could have been responsible and in the absence of any link with occupation. Although these cases were somewhat more common in males than females, their distribution suggests either a genetic aetiology or an environmental factor common to both sexes. The latter could conceivably include waterborne or airborne fibres originating from a wide range of naturally occurring minerals. The occurrence of mesothelioma in childhood leads to similar conclusions. Evidence of such cases was found in three surveys, the largest of which by FrAIRE et al. [64] recorded 80 cases in childhood, in only two of which was exposure to asbestos at all likely. Unless the usual latency with asbestos-related cases is much shorter in childhood, the existence of these cases suggests that there must have been some other cause.

Less conclusive support for a background incidence is afforded by the results of lung burden analyses in three case-control studies in North America and the UK, which are described more fully in the next section. In all three, a proportion of cases could not be attributed either to amphibole or chrysotile fibres. However, the small number of cases examined and the limits of fibre detection by electron microscopy reduce the confidence that can be put on negative findings.

More robust epidemiological evidence is given by mortality statistics for mesothelioma over the past 50 yrs or so. In most industrialized countries, the disease has increased much more rapidly in males than females, reflecting the impact of occupational asbestos exposure 30-40 yrs earlier. Backward extrapolation of these trends suggests that, before the diverging pattern began, mortality was about 1-2 per million population in both sexes. This conclusion is supported by data from countries or regions with low mesothelioma mortality, where both male and female rates are at about this level, and by data for California, USA, after exclusion of occupationally related cases [65].

If indeed there always has been a low background incidence of malignant mesothelial tumours unrelated to the industrial exploitation of asbestos, there remains the question of its aetiology. There are no indications that asbestos as it occurs naturally has been responsible, although this possibility would be difficult to refute. Similarly, although there are widespread deposits of other fibrous minerals, such as erionite and tremolite, which could conceivably 
cause sporadic disease, there is very little evidence that they do. In special circumstances, however, where local rock has been used for domestic whitewash, as in New Caledonia and several Mediterranean countries [6668], exposure to fibrous tremolite from childhood may well have led to a substantial number of cases. A number of other agents, such as biogenic silica fibre from burned-off sugar cane, some heavy metals (especially beryllium) and ionizing radiation have also been cited but none confirmed.

\section{Neighbourhood and domestic exposure}

The question thus comes down to whether the industrial use of asbestos - amphibole fibres in particular can lead to sufficient environmental pollution outside the workplace to cause nonoccupational cases. It is fairly clear that such cases do occur, but rarely. The evidence is strongest in cases presumably resulting from domestic exposure among the household contacts of asbestos workers. Such cases were documented in several papers mentioned by GARDNER and SARACCI [69] in a recent review, in most of which crocidolite was probably responsible. The occurrence of neighbourhood cases has also been described in the immediate vicinity of crocidolite mines in South Africa and Australia [69], and of factories which used these fibres in London, UK, and Hamburg, Germany, $[11,16]$. Most other studies of neighbourhood exposure have been negative.

More difficult to investigate is the possibility that cases of mesothelioma may arise as a result of general urban air pollution with asbestos fibres - almost all chrysotile and usually very short - in industrial cities of North America and Western Europe. There is little or no direct evidence one way or another for this hypothetical risk. That it is probably small and almost certainly beyond the limits of detection is suggested both by exposureresponse findings in chrysotile miners and millers and by the fact that mortality in females in North America and Western Europe has shown little or no increase during the last 20-30 yrs. The latter holds despite the contribution of occupational and household exposure and the greater awareness by physicians and pathologists of mesothelioma during the same period [25].

\section{Lung burden studies}

Since the pioneering work of LANGER and PoOLEy [70] in the early 1970s, the use of analytical transmission electron microscopy to identify and quantify mineral fibres in lung tissue has introduced a technique of great potential value for epidemiological research. In the assessment of past exposure, its specificity and cumulative capacity are far greater than was possible from work histories and scanty environmental measurements. On the other hand, this approach is limited in practice by the highly selected availability of lung tissue, and by the varied penetration, persistence and distribution of mineral fibres in the respiratory tract. Also, the significance of fibres in lung tissue at death is affected by whether or not the disease mechanism is related to these same fibre qualities.

It was shown by Pooley [71] and Rowlands et al. [72] that there were substantial differences in the ability of chrysotile and amphibole fibres to penetrate and persist in lung tissue. Thus, only studies which are adequately controlled for time variables and in other important respects, and where the analyses are conducted blind and in parallel, provide reliable information. The six surveys listed in table 6 are those in which these requirements were largely met, but even so with results which cannot readily be compared or tabulated.

Whilst it is evident from all six studies that amphibole fibres over $8 \mu \mathrm{m}$ in length could have explained nearly all the cases and shorter fibres few if any, there are several arguments for and against the possibility that chrysotile may also have played some part. Certainly, the power of the multivariate analysis used by MCDONALD et al. [77] was not sufficient to negate findings from their univariate analysis or to imply incompatibility with the observation by ROGERs et al. [78] of a chrysotile excess in the few cases where amphiboles were absent. In the latter study, the selection of all controls from a single hospital in Sydney, Australia, over a short period of time and the lack of matched pairs threw some doubt on the comparability of the 25 cases and 31 controls without amphiboles.

More substantial questions have been raised over the validity of conclusions on the role of chrysotile obtained from lung analyses at autopsy. Some have argued that only analyses of pleural tissue would have any relevance, perhaps without appreciating that the lung is simply being used in epidemiology as a sampling device to reflect past airborne exposure and not a direct pathological effect. The fact remains that as chrysotile is of low persistence, concentrations found at death may be unrelated to what was inhaled over a lifetime and, indeed, may predominantly reflect only very recent exposure. These questions have been reviewed by MCDONALD [79], and more fully by CHURG [80]. In essence, the validity of lung burden measurements in epidemiology depends on: 1) how well they correlate with best estimates of past exposure; and 2) whether the investigations were controlled for time-related and other potentially confounding factors. For neither of these questions is the answer entirely clear. There is, indeed, evidence from a fairly small study by RowLANDS et al. [72] and a larger one by SÉBASTIEN et al. [81] of a reasonably good correlation with past environmental exposure both for chrysotile and for tremolite in miners and millers in Quebec, Canada, and also in American textile workers, but further confirmation of this kind is needed. On the more difficult matter of adequate control for confounders, even among the six studies shown in table 6 , not one was wholly adequate in this regard. It would seem unreasonable, even so, to reject entirely the consistent evidence which they present.

The association of fibrous tremolite with many chrysotile deposits, leading to low but varying contamination of the final product, was first identified by lung burden analysis in 1976 [71]. This discovery had two possible and conflicting implications: firstly, that these amphibole fibres might be disproportionately responsible for disease apparently due to chrysotile - particularly mesothelioma - but, secondly, that as a much more persistent fibre, it might simply serve as a marker of chrysotile no longer present. Before dismissing chrysotile as a cause of mesothelioma, therefore, note must be taken of the extent to which tremolite is found in lungs at autopsy in 
Table 6. - Analysis of mineral fibres in lung tissue from mesothelioma cases and controls

\begin{tabular}{|c|c|c|c|c|c|c|c|}
\hline $\begin{array}{l}\text { First } \\
\text { author }\end{array}$ & Year & [Ref.] & Country & Cases & Controls & $\begin{array}{l}\text { Odds ratio for } \\
\text { amphibole fibres* }\end{array}$ & Evidence on chrysotile \\
\hline JONES & 1980 & {$[73]$} & UK & $\begin{array}{l}86 \text { cases notified } \\
\text { by coroners \& } \\
\text { pathologists, } \\
1976\end{array}$ & $\begin{array}{l}56 \text { cases (lung cancer } 27, \\
\text { cerebrovascular disease } \\
\text { 29); matched for age, sex } \\
\& \text { place }\end{array}$ & 7.4 & $\begin{array}{l}\text { Chrysotile present in } 2 \\
\text { of } 4 \text { cases without } \\
\text { amphiboles }\end{array}$ \\
\hline MCDONALD & 1982 & {$[74]$} & $\begin{array}{l}\text { USA \& } \\
\text { Canada }\end{array}$ & $\begin{array}{l}99 \text { cases from } \\
\text { survey of } \\
\text { pathologists }\end{array}$ & $\begin{array}{l}\text { Secondary lung cancer; } \\
\text { matched for age, sex, date } \\
\text { and hospital }\end{array}$ & 3.8 & $\begin{array}{l}\text { In pairs where } \\
\text { amphibole content was } \\
<10^{6} \text { fibres } \cdot g^{-1} \text { closely } \\
\text { similar distributions of } \\
\text { chrysotile }\end{array}$ \\
\hline Mowe & 1985 & {$[75]$} & Norway & $\begin{array}{l}14 \text { cases, county } \\
\text { cancer registry, } \\
1970-1979\end{array}$ & $\begin{array}{l}28 \text { cases excluding malignant } \\
\text { and chronic pulmonary } \\
\text { disease; matched for age, sex, } \\
\text { year and residence }\end{array}$ & $\begin{array}{l}\quad 8.5 \\
\text { (based on } \\
\text { all types of } \\
\text { amphibole fibres) }\end{array}$ & Fibre type not identified \\
\hline GAUDICHET & 1988 & {$[76]$} & France & $\begin{array}{l}20 \text { cases from } \\
\text { Nantes district, } \\
1980-1982\end{array}$ & $\begin{array}{l}20 \text { each of adenocarcinoma } \\
\text { and squamous carcinoma, } \\
\text { secondary lung cancer and } \\
\text { cardiovascular disease; } \\
\text { matched for age, sex and } \\
\text { hospital }\end{array}$ & $\begin{array}{l}\text { amphibole fibre } \\
\text { concentration } \\
2-3 \text { times } \\
\text { higher than } \\
\text { in controls }\end{array}$ & $\begin{array}{l}\text { Similar concentration in } \\
\text { cases and controls }\end{array}$ \\
\hline MCDONALD & 1989 & {$[77]$} & Canada & $\begin{array}{l}78 \text { cases from } \\
\text { survey of } \\
\text { pathologists, } \\
1980-1984\end{array}$ & $\begin{array}{l}\text { Nonmalignant, nonrespiratory } \\
\text { disease; matched for age, sex, } \\
\text { date, hospital and type of } \\
\text { sample }\end{array}$ & $\begin{array}{l}6.6 \text { for fibres } \\
\geq 8 \mu \mathrm{m} \text { in } \\
\text { length }\end{array}$ & $\begin{array}{l}\text { Low level risk in } \\
\text { univariate analysis and } \\
\text { none in multivariate } \\
\text { analysis }\end{array}$ \\
\hline ROGERS & 1991 & {$[78]$} & Australia & $\begin{array}{l}221 \text { cases from } \\
\text { national } \\
\text { surveillance, } \\
\text { 1980-1985 }\end{array}$ & $\begin{array}{l}359 \text { tissue samples from a } \\
\text { hospital in Sydney excluding } \\
\text { nonmalignant respiratory } \\
\text { disease and abdominal cancer; } \\
\text { unmatched }\end{array}$ & $\begin{array}{l}16.6 \text { for fibres } \\
\geq 10 \mu \mathrm{m} \text { in } \\
\text { length }\end{array}$ & $\begin{array}{l}7 \text { of } 25 \text { cases and } 3 \text { of } \\
31 \text { controls without } \\
\text { amphibole fibres had } \\
\geq 10^{5} \text { fibres. } g^{-1} \text { chrysotile }\end{array}$ \\
\hline
\end{tabular}

*: calculated by Rogers et al. [78], from comparison of cases and controls above and below $10^{6}$ amphibole fibres. $\mathrm{g}^{-1}$.

this disease. Light is thrown on this question by several studies, of which that by McDonald et al. [77], being well-controlled, indicated that of 78 cases of mesothelioma from across Canada, perhaps $29 \%$ were due to tremolite. An investigation in the USA by RogGLi et al. [82], although without controls and therefore less interpretable in terms of cause and effect, identified tremolite fibres in unstated concentration in 55\% of 94 cases. Thus, some of the mesothelioma cases apparently attributable to tremolite may have resulted from low-level contamination of industrial chrysotile, for which tremolite is not only a marker but, as shown below, may indeed be the cause. It must also be remembered that fibrous tremolite is a common contaminant of several industrially exploited minerals other than chrysotile.

\section{The tremolite question}

The extensive programme of epidemiological research in the mines and mills of Quebec, Canada, which began 30 yrs ago, was undertaken in the belief, wrong as it turned out, that the results would reflect exposure to pure chrysotile. Any impurities in the ore body were considered to be of minor importance and unlikely to cause difficulties in interpretation. The geological data available tended to support this view. The first indication that the situation might be more complicated was revealed by the results of electron microscope analyses of lung tissue from ex-mine workers reported by POOLEY in 1976 [71] and Rowlands et al. [72] in 1982. Not only did this show that chrysotile fibres were not alone but that amphibole fibres in the tremolite series were also present and usually in even higher concentration. In part, this reflected a lesser ability of chrysotile to penetrate the smaller airways but the major factor was undoubtedly the greater durability of the amphibole fibres. Whatever the explanation, the possible importance of persistence in pathogenesis was immediately evident.

There are various reasons for taking this finding seriously in relation to mesothelioma. The most direct indication of the carcinogenic potency of mineral fibres in the tremolite series was seen in the small cohort of 406 Montana, USA, vermiculite miners and millers, results of which were published in 1986 (table 3). Among only 165 deaths, 21 were from lung cancer (standardized mortality rate (SMR) 2.45) and four from mesothelioma (proportional mortality rate (PMR) 24.2 per 1,000). At a comparable stage in the evolution of the chrysotile cohort in Quebec, Canada, among some 4,000 deaths, 10 were from mesothelioma (PMR 2.5 per 1,000$)$. The average cumulative exposures experienced by the two cohorts were 145 fibres $\cdot \mathrm{mL}^{-1} \cdot \mathrm{yr}^{-1}$ in Montana and over 1,000 fibres $\cdot \mathrm{mL}^{-1} \cdot \mathrm{yr}^{-1}$ in Quebec. A very rough calculation would, therefore, suggest that if about 1\% of the Quebec exposure was to tremolite, this amphibole fibre might explain the mesothelioma risk at both locations. At that time, however, there seemed to be no way in which this highly speculative hypothesis could be tested, let alone validated.

Further support for the general concept came to light a few years later in the case-control study based on lung tissue analyses of 78 mesothelioma deaths in Canada, 1980-1984 and matched referents [77]. Concentrations of amosite, crocidolite and tremolite, but not of chrysotile or any other identified mineral fibre, discriminated sharply between the two series. The attributable risk 
associated with tremolite was estimated by multivariate analysis, suggesting that perhaps 23 of the 78 cases were due to tremolite, including all nine in the Quebec mining region. After excluding these cases, there remained 14 of 69 (i.e. about 20\%) in the rest of Canada attributable to tremolite. Given that in the past crocidolite and amosite comprised less than $10 \%$ of all asbestos used commercially, it thus appeared possible that tremolite as a contaminant of chrysotile might explain most of the remaining cases.

A better opportunity to examine the hypothesis came a few years later when mortality in the Quebec cohort was updated [31]. By the end of 1988, 33 fatal cases of mesothelioma were identified in a total of 7,300 deaths from all causes (PMR 0.45 per 1,000) and by the end of 1992,38 cases in a total of over 8,000 deaths (PMR 0.47 per 1,000). Among the 33 cases ascertained before 1989, 20 were from Thetford Mines, eight from the town of Asbestos, and five from a small asbestos products factory in Asbestos where crocidolite had also been used. Statistical analysis showed that the mesothelioma incidence was about 2.5 times greater among miners and millers at Thetford Mines than Asbestos [83]. Data on lung tissue analyses by Sébastien from our earlier survey [81], although scanty, showed that tremolite fibre concentrations were 2-4 times greater at Thetford Mines than Asbestos (ratio of medians 2.4; ratio of means 3.3) [83].

More demanding analyses are currently being applied to the most recent cohort data, focusing entirely on the 24 mesothelioma cases from Thetford Mines, 22 of which were in males employed by the largest company in that area. Advantage is being taken of two important facts: firstly, that this company had originally comprised many smaller companies distributed over a fairly wide geographical area; and, secondly, that lungs from 83 former cohort members from the same company had been analysed by electron microscopy for another purpose some 5 yrs earlier [81]. A preliminary analysis, now published [85] has demonstrated a remarkably close correlation between the high incidence of mesothelioma in a localized area of five mines and the concentration of tremolite fibre in the lungs of men who had worked in them [77]. These findings suggest that the relatively low risk of mesothelioma associated with chrysotile mining and milling may be largely determined by tremolite fibre contamination. Further analyses, which are now in progress, are needed to test this hypothesis and its wide implications.

\section{Conclusion}

After nearly $40 \mathrm{yrs}$ of epidemiological research, the main determinants of malignant mesothelial tumours in man are reasonably clear. It could be said that this was apparent from the start, when WAGNER et al. [8] described a disease of long latency in workers who mined, milled and used crocidolite, and in their family contacts, but rarely in miners of other types of asbestos. Sadly, the picture soon became confused and our understanding clouded by controversy. It is worth considering the reasons for this.

A major factor was that, although it was evident from cohort studies of chrysotile miners and millers in the early 1970s that this type of fibre rarely caused mesothelioma, it was nearly 20 yrs before comparable information became available for miners and millers of crocidolite or amosite. It is understandable that investigators familiar with the disastrous experience of insulation workers in North America, thought to have been exposed to chrysotile and possibly amosite, found it difficult to believe that all types of asbestos were not equally harmful. Their regrettable conclusion was that the data from Quebec, Canada, were wrong, or worse - a view supported by laboratory experiments which showed that all fibre types were equally carcinogenic for rats.

Against a background of suspicion and recrimination, the results of the several important cohort studies published in the 1980s failed to have much effect on entrenched and conflicting views. For those who saw chrysotile as a mineral fibre of low carcinogenicity, the findings summarized in tables 3, 4 and 5 confirmed this opinion. For those of the other persuasion, no great difficulty was found in maintaining their disbelief: the uncertainties associated with mixed exposures, lack of information on exposure intensity, and statistical chance were often cited, but less flattering reasons were not far below the surface. The aphorism that "what a man would like to be true, that he more readily believes" probably applied to both sides.

Some resolution of this unhelpful controversy came with the use of lung tissue analyses in epidemiological research. Despite difficulties in interpretation of results and the absolute need for properly selected controls [79], these studies have shown two things and are on the way to testing a third. Firstly, the clear evidence of an overwhelming predominance, with dose-response, of amphibole fibres in mesothelioma cases. Secondly, that amphibole fibres persist in lung tissue, whereas chrysotile does not; thus, the short lifespan of laboratory animals could not deal adequately with tumours with a characteristic latency of $30-40$ yrs in men. Thirdly, the fact that it has been only by analysing lung tissue that the varying presence of fibrous tremolite has been demonstrated in chrysotile as produced commercially, and the growing probability that this previously unrecognized amphibole may be responsible for most cases of mesothelioma associated with heavy chrysotile exposures.

When peace finally returns to asbestos epidemiology, it may well be too late to restore chrysotile's soiled reputation. Like Caesar's wife, such materials must be beyond suspicion, and neither political nor administrative policies are easily reversed. The more important lessons from this saga probably relate to the screening and manufacture of asbestos substitutes - the man-made mineral and organic fibres. Given what we now know, it would surely be foolhardy, without extraordinary justification, to allow the widespread use of fibres which resemble crocidolite and tremolite physically and the amphiboles generally in their biological persistence.

\section{References}

1. Wagner E. Das tuberkelähnliche Lymphadenom. Arch Heilk 1870; 11: 495-525.

2. Saccone A, Coblenz A. Endothelioma of the pleura. Am J Clin Pathol 1943; 13: 188-207. 
3. Gloyne SR. Two cases of squamous carcinoma of the lung occurring in asbestosis. Tubercle 1935; 17: 5-10.

4. Wedler HW. Über den Lungenkrebs bei Asbestose. Dtsch Arch Klin Med 1943; 191: 189-209.

5. Weiss A. Pleurakrebs bei Lungenasbestose in vivo morphologisch gesichert. Medizinische 1953; 1: 93-94.

6. Leicher F. Primärer Deckzelltumor des Bauchfells bei Asbestose. Arch Gewerbepath Gewerbehyg 1954; 13: 382-393.

7. Cartier P. Abstract of discussion. Arch Indust Hyg Med 1952; 5: 262.

8. Wagner JC, Sleggs CA, Marchand P. Diffuse pleural mesothelioma and asbestos exposure in the North Western Cape Province. Br J Ind Med 1960; 17: 260-271.

9. Hammond E, Selikoff IJ, Churg J. Neoplasia among insulation workers in the United States with special reference to intra-abdominal neoplasia. Ann NY Acad Sci 1965; 132: 519-525.

10. Elmes PC, McCaughey WTE, Wade OL. Diffuse mesothelioma of the pleura and asbestos. Br Med J 1965; 1: 350-353.

11. Newhouse ML, Thompson H. Mesothelioma of pleura and peritoneum following exposure to asbestos in the London area. Br J Ind Med 1965; 22: 261-269.

12. McEwen J, Finlayson A, Mair A, Gibson AAM. Mesothelioma in Scotland. Br Med J 1970; 4: 575-578.

13. McDonald AD, Harper A, El Attar OA, McDonald JC. Epidemiology of primary malignant mesothelial tumours in Canada. Cancer 1970; 26: 914-919.

14. Rubino GF, Scansetti G, Donna A, Palestro G. Epidemiology of pleural mesothelioma in north-western Italy (Piedmont). Br J Ind Med 1972; 29: 436-442.

15. Ashcroft T. Epidemiological and quantitative relationships between mesothelioma and asbestos on Tyneside. J Clin Pathol 1973; 26: 832-840.

16. Hain E, Dalquen P, Bohlig H, Dabbert A, Hinz I. Retrospective study of 150 cases of mesothelioma in Hamburg area. Int Arch Arbeitsmed 1974; 33: 15-37.

17. Zielhuis RL, Versteeg JPJ, Planteydt HT. Pleural mesothelioma and exposure to asbestos: a retrospective casecontrol study in The Netherlands. Int Arch Occup Environ Health 1975; 36: 1-18.

18. UICC. Report and recommendations of the working group on asbestos and cancer. Ann NY Acad Sci 1965; 132: 706-721

19. McDonald JC, Becklake MR, Gibbs GW, McDonald AD, Rossiter CE. The health of chrysotile mine and mill workers of Quebec. Arch Environ Health 1974: 28: 61-68.

20. McDonald JC, McDonald AD, Gibbs GW, Siemiatycki $\mathrm{J}$, Rossiter CE. Mortality in the chrysotile asbestos mines and mills of Quebec. Arch Environ Health 1971; 22: 677-686.

21. McDonald AD, McDonald JC. Malignant mesothelioma in North America. Cancer 1980; 46: 1650-1656.

22. McDonald JC, McDonald AD. Epidemiology of mesothelioma from estimated incidence. Prev Med 1977; 6: 426-446.

23. McDonald JC. Health implications of environmental exposure to asbestos. Environ Health Perspect 1985; 62: 319-328.

24. Ross DJ, Sallie BA, McDonald JC. SWORD '94: surveillance of work-related and occupational respiratory disease in the UK. Occup Med 1995; 45: 175-178.

25. Peto J, Hodgson JT, Matthews FE, Jones JR. Continuing increase in mesothelioma mortality in Britain. Lancet 1995; 345: 535-539.

26. Baris YI, Artvinli M, Sahin LAA. Environmental mesothelioma in Turkey. Ann NY Acad Sci 1979; 330: 423- 432
27. IARC monographs on the evaluation of carcinogenic risks to humans. Vol. 42. Silica and Some Silicates. Lyon, France, IARC, 1987; pp. 225-239.

28. Das PB, Fletcher AG, Deodhare SG. Mesothelioma in an agricultural community of India: a clinicopathological study. Aust NZ J Surg 1976; 46: 218-226.

29. Rothschild H, Mulvey JJ. An increased risk for lung cancer mortality associated with sugar cane farming. $J$ Natl Cancer Inst 1982; 68: 755-760.

30. McDonald JC. Epidemiology of pleural cancer. In: Hirsch A, Goldberg M, Martin J-P, Masse R, eds. Prevention of Respiratory Diseases. New York, Marcel Dekker, 1993; pp. 65-79.

31. McDonald JC, Liddell FDK, Dufresne A, McDonald AD. The 1891-1920 birth cohort of Quebec chrysotile miners and millers: mortality 1976-1988. Br J Ind Med 1993; 50: 1073-1081.

32. Piolatto G, Negri E, La Vecchia C, Pira E, Decarli A, Peto J. An update of cancer mortality among chrysotile asbestos miners in Balangero, Northern Italy. $\mathrm{Br} J$ Ind Med 1990; 47: 810-814.

33. Sluis-Cremer GK, Liddell FDK, Logan WPD, Bezuidenhout BN. The mortality of amphibole miners in South Africa, 1946-1980. Br J Ind Med 1992; 49: 566-575.

34. Armstrong BK, De Klerk NH, Musk AM, Hobbs MST. Mortality in miners and millers of crocidolite in Western Australia. Br J Ind Med 1988; 45: 5-13.

35. McDonald JC, McDonald AD, Armstrong B, Sébastien P. Cohort study of mortality in vermiculite miners exposed to tremolite. Br J Ind Med 1986; 43: 436-444.

36. Thomas HF, Benjamin IT, Elwood PC, Sweetnam PM. Further follow-up study of workers from an asbestos/ cement factory. Br J Ind Med 1982; 39: 273-276.

37. Ohlson C-G, Hogstedt C. Lung cancer among asbestos/ cement workers: a Swedish cohort study and a review. Br J Ind Med 1985; 42: 397-402.

38. Gardner MJ, Winter PD, Pannett B, Powell CA. Followup study of workers manufacturing chrysotile asbestos/ cement products. Br J Ind Med 1986; 43: 726-732.

39. Hughes JM, Weill H. Asbestos exposure - quantitative assessment of risk. Am Rev Respir Dis 1986; 133: 5-13.

40. Finkelstein M. Mortality among employees of an Ontario asbestos-cement factory. Am Rev Respir Dis 1984; 129: 754-761.

41. Alies-Patin AM, Valleron AJ. Mortality of workers in a French asbestos cement factory 1940-1982. Br J Ind Med 1985; 42: 219-225.

42. Magnani C, Terracini G, Bertolone GP, et al. Mortalita per tumori e altre malattie del sistema respiratorio tra $\mathrm{i}$ lavoratori del cemento-amianto a casale Monferrato: una studia di coorte storico. Med Lav 1987; 6: 441-453.

43. Raffn E, Lynge E, Juel K, Korsgaard B. Incidence of cancer and mortality among employees in the asbestos-cement industry in Denmark. Br J Ind Med 1989; 46: 90-96.

44. Albin M, Jakobsson K, Attewell R, Johansson L, Welinder $\mathrm{H}$. Mortality and cancer morbidity in cohorts of asbestoscement workers and referents. Br J Ind Med 1990; 47: 602-610.

45. Neuberger M, Kundi M. Individual asbestos exposure: smoking and mortality - a cohort study in the asbestoscement industry. Br J Ind Med 1990; 47: 615-620.

46. McDonald AD, Fry JS, Woolley AJ, McDonald JC. Dust exposure in an American chrysotile textile plant. $\mathrm{Br} \mathrm{J}$ Ind Med 1983; 40: 361-367.

47. Dement JM, Brown DP, Okun A. Follow-up study of chrysotile textile workers: cohort mortality and case-control analyses. Am J Ind Med 1994; 26: 431-447. 
48. McDonald AD, Fry JS, Woolley AJ, McDonald JC. Dust exposure and mortality in an American factory using chrysotile, amosite, and crocidolite in mainly textile manufacture. Br J Ind Med 1983; 40: 368-374.

49. Peto J, Doll R, Hermon C, Binns W, Clayton R, Goffe T. Relationship of mortality to measures of environmental asbestos pollution in an asbestos textile factory. Ann Occup Hyg 1985; 29: 305-355.

50. McDonald AD, Fry JS, Woolley AJ, McDonald JC. Dust exposure and mortality in an American chrysotile asbestos friction products plant. Br J Ind Med 1984; 41: 151-157.

51. Newhouse ML, Sullivan KR. A mortality study of workers manufacturing friction materials: 1941-1986. $\mathrm{Br} \mathrm{J}$ Ind Med 1989; 46: 176-179.

52. Selikoff IJ, Hammond EC, Seidman H. Mortality experience of insulation workers in the United States and Canada, 1943-1976. Ann NY Acad Sci 1979; 330: 91-116.

53. Seidman H, Selikoff IJ, Hammond EC. Short-term asbestos work exposure and long-term observation. Ann NY Acad Sci 1979; 330: 61-89.

54. Acheson ED, Gardner MJ, Winter PD, Bennett C. Cancer in a factory using amosite asbestos. Int $\mathrm{J}$ Epidemiol 1984; 13: 3-10.

55. McDonald AD, McDonald JC. Mesothelioma after crocidolite exposure during gas-mask manufacture. Environ Res 1978; 17: 340-346.

56. Jones JSP, Smith PG, Pooley FD, et al. The consequences of exposure to asbestos dust in a wartime gasmask factory. In: Wagner JC, ed. Biological Effects of Mineral Fibres. 2. IARC Scientific Publications No. 30. Lyon, France IARC, 1980; pp. 637-653.

57. Talcott JA, Thurber RN, Kantor AF, et al. Asbestosassociated diseases in a cohort of cigarette-filter workers. N Eng J Med 1989; 321: 1221-1223.

58. Acheson ED, Gardner MJ, Pippard EC, Grime LP. Mortality of two groups of women who manufactured gas-masks from chrysotile and crocidolite asbestos: a 40 year follow-up. Br J Ind Med 1982; 39: 344-348.

59. Rossiter CE, Coles RM. HM Dockyard, Devonport: 1947 mortality study. In: Wagner JC, ed. Biological Effects of Mineral Fibres. 2. IARC Scientific Publications No. 30. Lyon, France, IARC, 1980; pp. 713-721.

60. McDonald AD. Abstract of discussion. In: Glen HW, ed. Proceedings of asbestos symposium. Johannesburg, South Africa, October 1977. National Institute for Metallurgy, Randburg, 1978; p. 82.

61. Langer AM, Nolan RP. Fibre type and burden in parenchymal tissues of workers occupationally exposed to asbestos in the United States. In: Bignon J, Peto J, Saracci R, eds. Non-occupational Exposure to Mineral Fibres. IARC Scientific Publications No. 90. Lyon, France, IARC, 1989; pp. 330-335.

62. McDonald JC, McDonald AD. Mesothelioma: is there a background? Eur Respir Rev 1993; 3 (11): 71-73.

63. Enterline PE, Henderson VL. Geographic patterns for pleural mesothelioma deaths in the United States, 19681981. J Natl Cancer Inst 1987; 79: 31-37.

64. Fraire AE, Cooper S, Greenberg SD, Baffler P, Langston C. Mesothelioma in childhood. Cancer 1988; 62: 838-847.

65. Peto J, Henderson BE, Pike MC. Trends in mesothelioma incidence and the forecast epidemic due to asbestos exposure during World War II. In: Peto R, Schneiderman M, eds. Quantification of Occupational Cancer. Banbury Report 9. ColdSpring Harbor NY, 1981; pp. 51-72.

66. Luce D, Brochard P, Quénel P, et al. Malignant pleural mesothelioma associated with exposure to tremolite. Lancet 1994; 344: 1777.

67. Boutin C, Viallat JR, Steinbauer J, Dufour G, Gaudichet
A. Bilateral pleural plaques in Corsica: a marker of nonoccupational asbestos exposure. In: Bignon J, Peto J, Saracci R, eds. Nonoccupational Exposure to Mineral Fibres. IARC Scientific Publications No. 90. Lyon, France, IARC, 1989; pp. 406-410.

68. McConnochie K, Simonato L, Mavrides P, et al. Mesothelioma in Cyprus. In: Bignon J, Peto J, Saracci R, eds. Nonoccupational exposure to mineral fibres. IARC Scientific Publications No. 90. Lyon, France, IARC, 1989; pp. 411-419.

69. Gardner MJ, Saracci R. Effects on health of non-occupational exposure to airborne mineral fibres. In: Bignon J, Peto J, Saracci R, eds. Nonoccupational Exposure to Mineral Fibres. IARC Scientific Publications No. 90. Lyon, France, IARC, 1989; pp. 375-397.

70. Langer AM, Pooley FD. Identification of single asbestos fibres in human tissues. In: Bogovski P, Gilson JC, Timbrell V, Wagner JC. Biological Effects of Asbestos. IARC Scientific Publications No. 8. Lyon, France, IARC, 1973; pp. 119-125.

71. Pooley FD. An examination of the fibrous mineral content of asbestos lung tissue from the Canadian chrysotile mining industry. Environ Res 1976; 12: 281-298.

72. Rowlands N, Gibbs GW, McDonald AD. Asbestos fibres in the lungs of chrysotile miners and millers. Ann Occup Hyg 1982; 26: 411-415.

73. Jones JSP, Roberts GH, Pooley FD, et al. The pathology and mineral content of lungs in cases of mesothelioma in the United Kingdom in 1976. In: Wagner JC, ed. Biological Effects of Mineral Fibres. Vol 1. IARC Scientific Publications No. 30. Lyon, France, IARC, 1980; pp. 187199.

74. McDonald AD, McDonald JC, Pooley FD. Mineral fibre content of lung in mesothelial tumours in North America. Ann Occup Hyg 1982; 26: 417-422.

75. Mowe G, Gylseth B, Hartveit F, Skaug V. Fibre concentration in lung tissue of patients with malignant mesothelioma: a case-control study. Cancer 1985; 56: 1089-1093.

76. Gaudichet A, Janson X, Monchaux G, et al. Assessment by analytical microscopy of the total lung fibre burden in mesothelioma patients matched with four other pathological series. Ann Occup Hyg 1988; 32 (Suppl. 1); 213-223.

77. McDonald JC, Armstrong B, Case B, et al. Mesothelioma and asbestos fibre type. Cancer 1989; 63: 1544-1547.

78. Rogers AJ, Leigh J, Berry G, Ferguson DA, Mulder HB, Ackad M. Relationship between lung asbestos fibre type and concentration and relative risk of mesothelioma: a case-control study. Cancer 1991; 67: 1912-1920.

79. McDonald JC. Tremolite, other amphiboles, and mesothelioma. Am J Ind Med 1988; 14: 247-249.

80. Churg A. Analysis of lung asbestos content. Br J Ind Med 1991; 48: 649-652.

81. Sébastien P, McDonald JC, McDonald AD, Case B, Harley R. Respiratory cancer in chrysotile textile and mining industries: exposure inferences from lung analysis. Br J Ind Med 1989; 46: 180-187.

82. Roggli VL, Pratt PC, Brody AR. Asbestos fiber type in malignant mesothelioma: an analytical scanning electron microscopic study of 94 cases. Am J Ind Med 1993; 23 : 605-614.

83. McDonald JC. Epidemiological significance of mineral fiber persistence in human lung tissue. Environ Health Perspect 1994; 102 (Suppl. 5): 221-224.

84. McDonald AD, Gibbs GW, Rowlands N. Chrysotile and tremolite lung content of Quebec miners. Ann Occup Hyg 1988; 32 (Suppl. 1): 1182-1183.

85. McDonald JC, McDonald AD. Chrysotile, tremolite, and mesothelioma. Science 1995; 267: 775-776. 